\title{
The Core Requirements of the International Rule of Law in the Practice of States
}

\author{
Noora Arajärvi ${ }^{1}$
}

Accepted: 9 March 2021 / Published online: 24 March 2021

(c) The Author(s) 2021

\begin{abstract}
Is it possible to identify some foundational elements of international law that can be generally accepted by all States? Can such core elements reach a normative threshold to be considered requirements rather than "values" or "virtues" ? And finally, what are these core requirements of the international rule of law? This contribution propositions that, indeed, such core elements exist, identifies them-non-arbitrariness, consistency and predictability-from the practice of States at the international level and conceptualises them as the minimum requirements of the international rule of law. It presents an empirical study of statements of governments at the United Nations (UN) during a five-year period (2012-2017), accompanying the relevant findings with references to decisions and opinions of the International Court of Justice (ICJ).
\end{abstract}

\section{Introduction}

'In a divided world, the concept of the rule of law is one of the greatest unifying factors, perhaps the greatest, the nearest we are likely to come to a universal principle.' 1

International legal order-in a greater scale than its national counterparts-must constantly defend and reassert its foundational, structural, institutional and operative elements against external assailants and internal heretics. Some claim that during the past decade the contestations have ascended to a new level and may challenge the core integrity of the international legal order. ${ }^{2}$ Similar claims pertaining to the

\footnotetext{
1 President of Cyprus at the 2012 High-level Meeting on the Rule of Law at the National and International Levels, summary record A/67/PV.3, p. 9.

${ }^{2}$ H. Krieger and G. Nolte, 'The International Rule of Law - Rise or Decline?-Points of Departure', 1 KFG Working Paper Series (2016), available online https://papers.ssrn.com/sol3/papers.cfm?abstract_ $\mathrm{id}=2866940$ (last visited 19 Feb 2021).
}

Noora Arajärvi

arajarvi@hertie-school.org

1 The Hertie School, Friedrichstrasse 180, 10117 Berlin, Germany 
disruption of the unity of international legal order have infiltrated mainstream scholarship since the early 2000s. ${ }^{3}$ Is it possible to identify some foundational elements of international law that can be generally accepted by all States? Can such core elements reach a normative threshold to be considered requirements rather than "values" or "virtues" 4 ? And finally, what are these core requirements of the international rule of law?

This contribution propositions that, indeed, such core elements exist, identifies them from practices of States at the international level and conceptualises them as the minimum requirements of the international rule of law. The strength of the contribution lies not so much in the outcome of the identification and dissection of these requirements but in the methodological exercise of analysing State (verbal) practice with the support of relevant jurisprudence. While some theorising has gone into defining the international rule of law, ${ }^{5}$ instead of the pie-in-the-sky approach this contribution presents an empirical study of statements of governments at the United Nations (UN) during a five-year period (2012-2017), accompanying the relevant findings with references to decisions and opinions of the International Court of Justice (ICJ). At the same time, neither the empirical material itself-what governments and judges say-nor its analysis are devout of normative content. On both levels, it is transparently maintained that the international rule of law and its elements - regardless of disagreement on their content-are essential and desirable features of a well-ordered international system. Nonetheless, the crux of this contribution is not in reinventing the normative but exploring and exposing the empirical. The author adopts (if conventional) normative assumption that the international rule of law is worth defending and advancing but such endeavour ought to follow what the main subjects of international law-the States-do and say.

In his landmark book on the rule of law, Tom Bingham suggested that "[i]f the daunting challenges now facing the world are to be overcome, it must be in important part through the medium of rules, internationally agreed, internationally implemented and, if necessary, internationally enforced. That is what the rule of law

\footnotetext{
${ }^{3}$ Most famously by Martti Koskenniemi, see the Report of the Study Group of the International Law Commission, Fragmentation of International Law: Difficulties Arising from the Diversification and Expansion of International Law, A/CN.4/L.682, 13 April 2006. See also P-M. Dupuy, 'A Doctrinal Debate in the Globalisation Era: on the "Fragmentation" of International Law', 1 (1) European Journal of Legal Studies (2007) 25.

4 Stéphane Beaulac, in his captivating piece, externalises core values of the rule of law onto international plane, whereas Chesterman, likewise in a seminal piece on the topic, notes the high degree of consensus on the virtues of the rule of law. See S. Beaulac, 'The Rule of Law in International Law Today', in G. Palombella \& N. Walker (eds.), Relocating the Rule of Law (2009) 197 and S. Chesterman, 'An International Rule of Law?', 56 (2) American Journal of Comparative Law (2008) 331.

5 A recent authoritative contribution by Robert McCorquodale 'sets out the objectives or elements of the international rule of law, being to uphold legal order and stability, to provide equality of application of the law, to enable access to justice for human rights, and to settle disputes before an independent legal body', R. McCorquodale, 'Defining the International Rule of Law: Defying Gravity', 65 (2) International and Comparative Law Quarterly (2016) 277, at 303-304.
} 
requires in the international order. ${ }^{6}$ Yet in political parlance at the UN one often hears that '[the rule of law] is an extremely broad concept that has no consensual definition or scope agreed upon by the [United Nations] Member States' ${ }^{7}$ Although 'in recent years, the importance of the rule of law in world affairs has been recognized on an increasingly frequent basis by the international community', 8 its substance remains disputed, for "there are almost as many conceptions of the rule of law as there are people defending it'. ${ }^{9}$ Hence, 'as blanket term ... "the rule of law" appears to be overused, of limited analytic or descriptive value, and potentially distorting. ${ }^{10}$ It would appear that the trepidation of the rule of law as a Trojan horse to import substantive goals, as depicted by Simon Chesterman in 2008, has materialised. Therefore-and serving as the general objective (and warning!) of this contribution-conceptual clarity is essential in unfolding what lies at the core of international rule of law. The aim is to respond to the overuse of the blanket term on one hand and to restore its analytical and descriptive value on the other, if in a limited capacity, and accepting that this is but one attempt: "[t]here may not be one single definition for the rule of law, but there are certain core elements that we can identify. 11

This contribution argues that non-arbitrariness, consistency and predictability form the core minimum requirements of the rule of law, which are acceptable for all States. The first section explicates the contour of the understanding of the 'rule of law' and engages with some relevant literature dedicated to the international rule of law. The second section introduces the notion of the rule of law and international rule of law at the United Nations. The third section then shows how the core requirements have been identified through the UN rule of law debates and expressed by States in the General Assembly (UNGA). These findings are discussed in relation to relevant ICJ jurisprudence. Building on this, the final section draws some conclusions from the findings and demonstrates why it is crucial to foster conceptual clarity in discussing the international rule of law.

\footnotetext{
${ }^{6}$ T. Bingham, The Rule of Law (2010), at 129.

${ }^{7}$ Remarks by the Russian delegation on the proposed SDG 16, Open Working Group on Sustainable Development Goals, Achieve peaceful and inclusive societies, rule of law, effective and capable institutions (19 June 2014), available at https://sustainabledevelopment.un.org/content/documents/10494russia. pdf (last visited 27 February 2021).

${ }^{8}$ Judge P. Tomka, The Rule of Law and the Role of the International Court of Justice in World Affairs (2013), available at https://www.icj-cij.org/public/files/press-releases/8/17848.pdf (last visited 27 February 2021).

9 O. Taiwo, 'The Rule of Law: The New Leviathan?', 12 Canadian Journal of Law and Jurisprudence (1999) 151, at 154.

${ }^{10}$ S. Humphreys, Theatre of the Rule of Law: Transnational Legal Intervention in Theory and Practice (2010), at xxv; illustrated also by Croatia's statement at the 2012 High-level meeting: ' $\ldots$ the rule of law should cover every aspect of the daily political and social life of all citizens around the world.' A/67/ PV.3, p. 34.

${ }^{11}$ Minister of Foreign Affairs of Malaysia at the 2012 high-level meeting. Summary record A/67/PV.5, p. 11.
} 


\section{Defining the International Rule of Law}

The international rule of law has not developed in a vacuum: its conceptual roots, practices and reflections in judicial decisions inevitably draw from the notion of the rule of law at the national level. ${ }^{12}$ Nevertheless, it has been accurately argued that the domestic rule of law concept, its content and meaning cannot be simply transposed, implemented or internalised at the international level for various reasons: the horizontal hierarchy of actors, de-centralised law-making, lack of effective judicial review mechanisms, and pluralist notions of justice, to mention just some. ${ }^{13}$ The rule of law and the international rule of law are two distinct concepts, which evolved in response to different sets of issues and problems. ${ }^{14}$ Therefore, I provide a very brief overview of central doctrinal positions in the general rule of law debate and the interfaces between the two concepts, before proceeding with the focus on the international rule of law and its core requirements.

According to Sir Arthur Watts, national understandings of the rule of law are at best an approximate guide to the content of their international analogue. ${ }^{15}$ In this view, many elements of the rule of law at the national level are simply not equivalent for the purposes of the international legal order. His reasoning stems from the specific requirements of the rule of law in the domestic contexts, often reflective of a State's particular historical and constitutional evolution. While the rule of law at the national level may focus legitimately on the protection of rights of the individual against the State, the rule of law at the international level is primarily concerned with the coordination of inter-State interactions. ${ }^{16}$ James Crawford has expressed the view that the international rule of law as an analogue to the domestic concept is conditioned by certain facts, notably the absence of legislative power such as it exists in domestic legal systems, and the correlative need for many decisions to be made by consensus of the States. ${ }^{17}$ For similar reasons, Hisashi Owada calls for a reconceptualization of the rule of law in the international context, even though certain elements

\footnotetext{
${ }^{12}$ For authoritative discussion, see M. Kanetake, 'The Interfaces Between the National and International Rule of Law: A Framework Paper', 11, in M. Kanetake and A. Nollkaemper The Rule of Law at the National and International Levels: Contestations and Deference (2016).

${ }^{13}$ E.g. P. Burgess, 'Deriving the international Rule of Law: an unnecessary, impractical and unhelpful exercise', 10 (1) Transnational legal theory (2019) 65; Chesterman (2008), supra note 4.

${ }^{14}$ I. Hurd, 'The international rule of law and the domestic analogy', 4 (3) Global Constitutionalism (2015) 365 ;

15 A. Watts, 'The International Rule of Law', 36 German Yearbook of International Law (1993) 15, at 16.

${ }^{16}$ For a well-reasoned but contrary position, acclaiming that ' $\ldots$ one of the main goals of an international rule of the law is the protection of individual and state autonomy from the arbitrary interference of international institutions', see C. E. Pavel, 'The international rule of law', 23 (3) Critical Review of International Social and Political Philosophy (2020) 332, at 334.

17 J. Crawford, 'International Law and the Rule of Law', 24 Adelaide Law Review (2003) 3, at 10; J. Crawford, Chance, Order, Change: The Course of International Law-General Course on Public International Law (2014), at 353.
} 
of the rule of law remain so essential that they should be applicable in interstate relations as they are in the domestic realm. ${ }^{18}$

The international rule of law has purposes beyond limiting arbitrary use of power. ${ }^{19}$ Due to the lack of vertical power paradigm in international relations, the international rule of law purports to regulate relations-whether or not consisting of exercise of authority- between actors. Machiko Kanetake has classified these relations as 'horizontal state-to-state relations, authority exercised by the government against individuals and non-state entities, and authority exercised by international institutions'. ${ }^{20}$ She also provides a sketch of specific national and international rule of law elements with an aim similar but methodologically contrasting to the present study. Kanetake approaches the elements of the international rule of law by taking 'major rule of law elements adopted at the national level [as analytical support], and see[ing] if they can be found in international legal practices'. Relevant is also her acknowledgment of non-substantive qualities of the law, 'such as non-retrospectivity, openness, and certainty of law', with a reference to Joseph Raz. ${ }^{21}$

At the current point in time in the evolution of international law, it is no longer necessary to transpose, implant or utilise domestic rule of law notions in order to find the international rule of law. This does not negate the fact that many of these concepts are nonetheless deeply rooted into political philosophy and command our thinking of any legal or political system. The issue concerns more the starting premise of discussion: are we looking to find concepts or requirements predetermined by domestic settings (or our thinking about them) or are we willing to see what concepts emerge in the international legal order?

While classically international lawyers have viewed the system through their domestic monocle, such restraint should be set aside, taking a fresh look at international law, and in this context, carving out the core notion of the rule of law at the international level, which attracts universal acceptance. ${ }^{22}$ While vouching for international international legal scholarship free of national conceptual constraints, I acknowledge the irony in looking at statements of States to find the core of international rule of law. This, in my view, however, does not pose an oxymoron but rather a restatement of classic international law doctrine: I argue that we cannot accurately identify rules (primary, secondary, meta) of international law by looking at what States say and do at home but rather through their actions and statements at the international level. It is through those actions and statements that States interact with and-intentionally or inadvertently_-shape international law. As Brian Tamanaha has persuasively argued:

\footnotetext{
${ }^{18}$ H. Owada, 'Reconceptualitzation of the International Rule of Law in a Globalizing World', 51 Japanese Yearbook of International Law (2008) 3, at 10.

19 In Joseph Raz's words, 'the rule of law is designed to minimize the danger created by the law itself' (Authority of Law, at 224).

${ }^{20}$ Kanetake (2016), supra note 12.

21 Ibid., at 9.

${ }^{22}$ For example, President of the ICJ, R. Higgins, The ICJ and the Rule of Law (2007), available at https://archive.unu.edu/events/files/2007/20070411_Higgins_speech.pdf (last visited 27 February 2021).
} 
[i]f there is to be an enduring international rule of law it must be seen to reflect the interests of the entire international community. Otherwise there is little prospect of pervasively entrenching the requisite belief that international law is worthy to rule. ${ }^{23}$

At the international level, the commitment of States to the minimum requirements of the international rule of law extends to meta-normative level but can be found in solid (verbal and physical) practice without embracing an ethically thick concept. ${ }^{24}$ This contribution approaches the core of the international rule of law as a set of requirements illustrated and identifiable in legal (argumentative) practice and semantics (even if presented in a politically charged forum). Adopting a pragmatist approach converging the normativity of law from social facts and practices allows one to identify shared understandings, which in turn can set parameters for criteria of legality, which form (core) of the international rule of law. ${ }^{25}$ Here, engagement with the practice-focused conception of the rule of law goes on to show States' general acceptance, through (verbal) practice, of these core requirements. The core requirements of the international rule of law are not a part of ordinary legal rules. They serve a normative function broader, deeper and higher than the primary or secondary rules of international law and could be construed in a sense of an international rule of recognition. ${ }^{26}$ In this contribution, the focus is grounded on unveiling these requirements and while transparently siding with positivist understanding of law, the discussion on Hartian international rule of law-however compelling-will be left for another day.

A meaningful definition capable of underlying the international legal order thus needs to be able to justify itself to the legal subjects. Since States continue to be the primary subjects of international law, their legal opinions and practices need to be assessed in order to identify these distinguishing features. Yet I am not vouching that the requirements of international rule of law be based on full, universal and explicit consent of States but a general acceptance, which is neither controversial nor broadly contested. At the international level, we can identify a 'modest rule of law, 27 - and to foster and build on its resilience we must exercise analytical cautiousness in avoiding substantive overreaching. While the views expressed by States

\footnotetext{
23 B. Tamanaha, On the Rule of Law (2004), at 136.

24 See e.g. T. Roux, 'A Normatively Inflected, Sociologically Aware Account of the Rule of Law', 11 Hague Journal on the Rule of Law (2019) 295.

25 E.g. J. Brunnée and S. Toope, 'Interactional international law: an introduction', 3 (2) International Theory (2011) 307. See also a recent discussion on the topic: K. Gorobets, 'The International Rule of Law and the Idea of Normative Authority', 12 Hague Journal on the Rule of Law 227.

26 For discussion, see C.E. Pavel, 'Is International Law a Hartian Legal System?', 31 (3) Ratio Juris (2018) 307;

D. Lefkowitz, 'The Sources of International Law: Some Philosophical Reflections', 187 in S. Besson and J. Tasioulas, The Philosophy of International Law (2010); and D. Lefkowitz, 'H.L.A. Hart: Social Rules, Officials, and International Law', at 20, in D. Lefkowitz, Philosophy and International Law: A Critical Introduction (2020).

27 J. Brunnée and S. J. Toope, 'Interactional legal theory, the international rule of law and global constitutionalism', in A. F. Lang and A. Wiener (eds.), Handbook on Global Constitutionalism (2017) 170, AT 171.
} 
serve as the starting point for identifying these requirements, judicial decisions and academic writings are highly relevant as subsidiary means for their further interpretation and rationalisation.

\section{International Rule of Law in the UN System}

The normative foundation of the international rule of law in the UN framework is embedded in the Charter of the United Nations. ${ }^{28}$ The Preamble of the Charter expresses the determination of the founding Members of the Organization 'to establish conditions under which justice and respect for the obligations arising from treaties and other sources of international law can be maintained'. ${ }^{29}$ In the UN instruments, the term 'rule of law' first appeared in the Universal Declaration of Human Rights of 1948, the preamble recognising '... human rights should be protected by the rule of law ....30

The question of the rule of law as a legal concept and as a political idea is reflected throughout the debates at the UN, which explicate the pendulum between the 'thin' and the 'thick' definitions, ${ }^{31}$ and both process-oriented and substantive elements are regularly discussed. ${ }^{32}$ In 2004 the concept was given substance when the Secretary-General defined the rule of law as

a principle of governance in which all persons, institutions, and entities, public and private, including the State itself, are accountable to laws that are publicly promulgated, equally enforced and independently adjudicated, and which are consistent with international human rights norms and standards. It requires, as well, measures to ensure adherence to the principles of supremacy of law, equality before the law, accountability to the law, fairness in the application of the law, separation of powers, participation in decision-making, legal certainty, avoidance of arbitrariness and procedural and legal transparency. ${ }^{33}$

\footnotetext{
28 But not unanimously: For instance, in the 2015 Sixth Committee debate, Russia reiterated its objection to viewing the rule of law as an inalienable part of the Charter, stating that the Charter does not mention 'rule of law' at all, only referring to 'international law'. Russia has also objected to the Secretary-General's 2004 definition of the concept.

29 Charter of the United Nations, 24 October 1945, 1 UNTS XVI. For analysis, see B. Fassbender, 'What's in a Name? The International Rule of Law and the United Nations Charter', 17 Chinese Journal of International Law (2018) 761.

${ }^{30}$ Universal Declaration of Human Rights, General Assembly resolution 217 A (III), Preamble.

31 E.g. Chesterman (2008), supra note 4; R. Collins, 'Two idea(1)s of the international rule of law', 8 (2) Global Constitutionalism (2019) 191; J. Møller and S-E. Skaaning, 'Systematizing Thin and Thick Conceptions of the Rule of Law', 33 (2) Justice System Journal (2012) 136; M. Krygier, 'Rule of Law (and Rechtsstaat)', 45, in J. R., Silkenat., J. E. Hickey \& P. D. Barenboim, (eds.).The Legal Doctrines of the Rule of Law and the Legal State (Rechtsstaat) (2014).

32 For instance, as set out by the Jamaican delegation at the 2012 High-level meeting: 'the foundation principles of justice, fairness, accountability and transparency are inextricably linked to [the rule of law's] effective enforcement at the international level.' Jamaica, A/67/PV.5, p. 7.

33 Report of the Secretary-General: The rule of law and transitional justice in conflict and post-conflict societies, 23 August 2004, S/2004/616, para. 6.
} 
With the benefit of hindsight, this thick definition was perhaps an overreach on the part of the Secretary-General, or it may not have been intended to be taken as a holistic reference point. At the same time, it speaks to the rule of law at the national level rather than providing an insight into what may lie at the core of international rule of law. ${ }^{34}$

While no formal definition of the rule of law had been agreed upon by Member States, the discussions began to gain momentum after the 2005 World Summit. ${ }^{35}$ The normative relevance of the rule of law was becoming recognised as 'an increasingly relevant reference point against which the behaviour of states is assessed under international law'. ${ }^{36}$ The World Summit Outcome highlighted the need for 'universal adherence to and implementation of the rule of law at both the national and international levels' ${ }^{37}$ and reaffirmed Member States' commitment to 'an international order based on the rule of law and international law.'. ${ }^{38}$

In September 2012, the General Assembly held the High-level meeting on the rule of law at the national and international levels. In the resulting Declaration, ${ }^{39}$ the Member States reaffirmed their 'solemn commitment to the purposes and principles of the Charter of the United Nations, international law and justice, and to an international order based on the rule of law, which are indispensable foundations for a more peaceful, prosperous and just world. ${ }^{40}$ Although previous drafts of the High-level declaration repeated the definition of the rule of law as set out in the 2004 Report of the Secretary-General, ${ }^{41}$ on the final text the Member States failed to agree on a definition of the rule of law due to conflicting political interests and protective attitude over aspects that-many considered--may impair State sovereignty and national ownership. ${ }^{42}$ States also avoided using language implying that the rule of law is a binding principle of international law, and rededicated themselves 'to support all efforts to uphold the sovereign equality of all States, to respect their

\footnotetext{
${ }^{34}$ For eloquent discussion, see R. McCorquodale 'Defining the International Rule of Law: Defying Gravity', 65 (2) International and Comparative Law Quarterly (2016) 277, at 286.

35 For an overview of the 'rise' of the rule of law at the UN between 1993 and 2008, see T. Fitschen, 'Inventing the Rule of Law for the United Nations', 12 Max Planck Yearbook of United Nations Law (2008) 347.

${ }^{36}$ H. Aust and G. Nolte, 'International Law and the Rule of Law at National Level', in M. Zürn, A. Nollkaemper and R. Peerenboom (eds), Rule of Law Dynamics in an Era of International and Transnational Governance (2012) 48, at 67.

372005 World Summit Outcome, 24 October 2005, A/RES/60/1, para. 134.

38 Ibid., para. 134 (a).

39 Declaration of the high-level meeting of the General Assembly on the rule of law at the national and international levels, adopted 24 September 2012, A/RES/67/1.

40 Ibid., para. 1. For analysis of the Declaration and the negotiations, see C. Feinäugle, 'The UN Declaration on the Rule of Law and the Application of the Rule of Law to the UN: A Reconstruction From an International Public Authority Perspective', 7 Goettingen Journal of International Law (2016) 157.

41 E. Selous, 'The Rule of Law and its Application to the United Nations' in C.A. Feinäugle (ed), The Rule of Law and Its Application to the United Nations (2016), 13, at 25.

42 For instance, Bulgaria noted that, "the final text does not fully reflect our views on the fundamental link between legality, accountability, democratic governance and human rights, we hope that it will provide a good starting point for future dialogue and cooperation on how best the rule of law should be applied at the national and international levels.' (A/67/PV.3, p. 17).
} 
territorial integrity and political independence..., ${ }^{43}$ and recognising the importance of national ownership in rule of law activities'. ${ }^{4}$

Paragraph 2 of the High-level Declaration contains those general definitional parameters that the membership could agree on:

We recognize that the rule of law applies to all States equally, and to international organizations, including the United Nations and its principal organs, and that respect for and promotion of the rule of law and justice should guide all of their activities and accord predictability and legitimacy to their actions. We also recognize that all persons, institutions and entities, public and private, including the State itself, are accountable to just, fair and equitable laws and are entitled without any discrimination to equal protection of the law.

Equally noteworthy is to recognise what was left out of that paragraph, namely, any reference to human rights, separation of powers, participation in decision-making, and procedural and legal transparency. ${ }^{45}$ Although the pursuit for a clear, universally acceptable definition of the international rule of law proved to be hopeless during the 2012 High-level Meeting and the Declaration, the statements delivered during the High-level meeting and, importantly, in the subsequent rule of law debates in the Sixth Committee of the UNGA shed light into understanding of how States perceive the international rule of law and its core requirements. The definition (or lack thereof) of the international rule of law was a topic of a heated debate also during the post-2015 process leading up to the 2030 Agenda and the Sustainable Development Goals. Given the particular scope in the context of development, the analysis of this debate falls outside of this contribution and has been discussed at length elsewhere. ${ }^{46}$

\section{UN Rule of Law Debates from 2012 to 2017}

This summary study is thematically rather than chronologically organised, as many States stress the same points in each annual statement. The next subsections illustrate the overall support for the core requirements of the international rule of law but do not present a quantified analysis of each and every statement by all States during the five-year period. It is noteworthy that at the GA States usually omit delving into conceptual questions and have a limited allocated time to explain the meaning and context of their positions. In conducting an analysis of this kind one should not be too hasty or incautious in ascribing positions to States but rather keenly to scrutinise whether statements are intended to carry merely political or also some legal impetus.

\footnotetext{
43 High-level declaration, para. 3.

44 High-level declaration, para 11.

45 See E. Selous (2016), 25.

46 See I. Khan, 'Shifting the Paradigm: Rule of Law and the 2030 Agenda for Sustainable Development' 7 World Bank Legal Review (2016) 221; N. Arajärvi, 'The Rule of Law in the 2030 Agenda', 10 (1) The Hague Journal on the Rule of Law (2018) 187.
} 
Still, if there is one public, multilateral, forum where States can be expected to voice their genuine concerns, views and positions, it is that of the UN General Assembly. While I am not making a claim that the General Assembly, its resolutions, or practice of States in the General Assembly would constitute law or have law-forming qualities beyond being affirmative of lex lata or on occasion reflecting lex ferenda ${ }^{47}$ it has been authoritatively noted by the International Law Commission that practice contributing to the formation of rules of international law 'may take a wide range of forms' ${ }^{48}$ In this context, it is acknowledged that State practice includes conduct in connection with resolutions adopted by an international organization. This is not to suggest that the requirements of international rule of law identified here would necessarily form a part of customary international law, but that possibility is not excluded either. It would require, however, assessment of further evidence and with somewhat of a different approach to the one adopted in the current study, in order to determine the actual existence and extent of State practice and its acceptance in the form of opinio juris.

The following analysis also discusses the jurisprudence of ICJ, with the underlying assumption that judicial practice is aimed at authoritatively recognising sources and legal rules, and that the resulting decisions and opinions reflect international practice for the purposes, here, of identifying the requirements of international rule of law. ICJ, as the principal judicial organ of the $\mathrm{UN},{ }^{49}$ is the only standing international court of a universal character with general jurisdiction. ${ }^{50}$ Even though numerous separate and dissenting opinions of judges at the ICJ have referred to the (international) rule of law, ${ }^{51}$ only three majority decisions mention the rule of law and offer an insight into the understanding of the concept by the Court. Decision of some regional courts are also referred to on occasions where they have directly addressed a point under discussion.

\footnotetext{
${ }^{47}$ E.g. S.M. Schwebel, 'The Effect of Resolutions of the U.N. General Assembly on Customary International Law', 73 Proceedings of the Annual Meeting (American Society of International Law) (1979), at 301-309; N. Arajärvi, 'From the "Demands of Humanity": The Formulation of Opinio Juris in Decisions of International Criminal Tribunals and the Need for a Renewed Emphasis on State Practice', in B.D. Lepard, (ed.), Re-examining Customary International Law (2017), 189 at 194-196.

48 Draft conclusion 6, International Law Commission, 'Draft conclusions on identification of customary international law, with commentaries', A/73/10, Yearbook of the International Law Commission (2018) vol. II, Part Two.

49 Article 92 UN-Charter.

${ }^{50}$ Report of the ICJ 2017-2018, UN Doc. A/73/4, at 12 para 33.

51 For example, Jurisdictional Immunities of the State (Germany v. Italy: Greece intervening), Judgment, 3 February 2012, ICJ Reports (2012) 99, Dissenting opinion of Judge Antônio Augusto Cançado Trinidade, at 236, para 150; Application of the International Convention on the Elimination of All Forms of Racial Discrimination (Georgia v. Russian Federation), Preliminary Objections, Judgment, 1 April 2011, ICJ Reports (2011) 70, Dissenting opinion of Judge Cançado Trindade, at 298, para 141; Accordance with International Law of the Unilateral Declaration of Independence in Respect of Kosovo, Advisory Opinion, 22 July 2010, ICJ Reports (2010) 403, Declaration of Judge Simma, at 480, para 8; Legality of the Threat or Use of Nuclear Weapons, Advisory Opinion, 8 July 1996, ICJ Reports (1996) 226, Dissenting Opinion of Judge Weeramantry, at 551.
} 


\subsection{Non-arbitrariness}

Since 2012, the Movement of Non-Aligned States has consistently demanded that the international rule of law must be anchored in the principle of sovereign equality. ${ }^{52}$ As this Movement consists of 120 States its concerns shall be taken seriously, especially since many Non-Aligned States have in addition declared in their individual capacity that sovereign equality constitutes the basis of the international rule of law. ${ }^{53}$ Furthermore, 33 CELAC States, ${ }^{54}$ the Russian Federation, ${ }^{55}$ Canada, Australia and New Zealand, ${ }^{56}$ the five Nordic countries, ${ }^{57}$ as well as China ${ }^{58}$ have explicitly expressed their support for sovereign equality as central in the rule of law discussions. Sovereign equality is closely related to the core requirement of non-discrimination.

The rationale behind this demand for the respect of sovereign equality of the States appears to lie in an understanding that the rule of law is the opposite of rule of power, ${ }^{59}$ and politicization has to be avoided..$^{60}$ The international rule of law

\footnotetext{
52 Islamic Republic of Iran on behalf of NAM (A/C.6/72/SR.5, § 23); Islamic Republic of Iran speaking on behalf of NAM (A/C.6/71/SR.4, § 89), (A/C.6/70/SR.5, § 19), (A/C.6/69/SR.4, § 81).

${ }^{53}$ Cambodia on behalf of AEAN (A/C.6/72/SR.5, § 48); Qatar (A/C.6/72/SR.5, § 100); Senegal (A/C.6/72/SR.6, § 37); Nicaragua (A/C.6/72/SR.6, § 80 f.); Rwanda (A/C.6/72/SR.6, § 103); Sri Lanka (A/C.6/72/SR.6, § 109); Viet Nam (A/C.6/72/SR.7, § 31); Morocco (A/C.6/72/SR.7, § 81); Bolivarian Republic of Venezuela (A/C.6/72/SR.7, § 91); Islamic Republic of Iran (6th Committee, 72nd session, 5 October 2017, available at: http://statements.unmeetings.org/media2/16152832/iran-islamic-republicof-.pdf); Qatar (A/C.6/71/SR.5, § 49); Lebanon (A/C.6/71/SR.5, § 64); Myanmar (6th Committee, 71st session, 6th October, available at: http://statements.unmeetings.org/media2/7661267/myanmar-final-. pdf); India (6th Committee, 71st session, 6th October, available at: http://statements.unmeetings.org/ media2/7661336/india.pdf); Sri Lanka (A/C.6/71/SR.6, § 29); Maldives (6th Committee, 71st session, 5th October 2016, available at: http://statements.unmeetings.org/media2/7661351/maldives.pdf); Islamic Republic of Iran (A/C.6/71/SR.7, § 42); Philippines (A/C.6/71/SR.7, § 73); Belarus (A/C.6/70/SR.6, § 2); Sudan (A/C.6/70/SR.6, § 8); Sri Lanka (A/C.6/70/SR.6, 76); Nigeria (A/C.6/70/SR.6, § 81); Indonesia (A/C.6/70/SR.7, § 21); Syria (A/C.6/70/SR.7, § 42 and § 45); Viet Nam (A/C.6/70/SR.7, § 61); Pakistan (A/C.6/70/SR.7, § 95); Philippines (6th Committee, 70th session, 15th October 2015, available at: http://statements.unmeetings.org/media2/7653051/philippines.pdf); Democratic Republic of the Congo (A/C.6/69/SR.5, § 48); Qatar (A/C.6/69/SR.5, § 52); Libya (A/C.6/69/SR.5, § 58); Pakistan (A/C.6/69/ SR.5, § 62); Viet Nam (A/C.6/69/SR.6, § 19); Philippines (A/C.6/69/SR.6, § 28); Nigeria (A/C.6/69/ SR.6, § 68); Algeria (A/C.6/69/SR.6, § 92); Guinea (A/C.6/69/SR.6, § 96); Syrian Arab Republic (A/C.6/69/SR.7, § 35); Zimbabwe (A/C.6/69/SR.7, § 60); Jordan (A/C.6/69/SR.8, § 9).

${ }^{54}$ Dominican Republic speaking on behalf of CELAC (A/C.6/71/SR.4, § 80); Ecuador on behalf of CELAC (A/C.6/70/SR.5, § 41), reiterated by Bolivarian Republic of Venezuela (A/C.6/72/SR.7, § 91), Nicaragua (A/C.6/72/SR.6, § 80 f.), Paraguay (A/C.6/70/SR.6, § 67), El Salvador (A/C.6/70/SR.8, § 8), and Mexico (A/C.6/69/SR.7, § 41).

55 (A/C.6/71/SR.5, § 43), (A/C.6/69/SR.5, § 78).

${ }^{56}$ Canada on behalf of Canada, Australia and New Zealand [CANZ] (6th Committee, 70th session, 14th October 2015, available at http://statements.unmeetings.org/media2/7652805/canada-on-behalf-of-canz. pdf).

57 Finland, speaking on behalf of the Nordic countries Denmark, Finland, Iceland, Norway and Sweden (A/C.6/69/SR.5, § 18).

58 (A/C.6/69/SR.7, § 31).

${ }^{59}$ Islamic Republic of Iran (A/C.6/70/SR.7, § 41); (A/C.6/69/SR.7, § 23).

${ }^{60}$ Sudan (A/C.6/71/SR.5, § 63); Jordan (A/C.6/69/SR.8, § 9).
} 
should protect against the unilateral imposition of values. ${ }^{61}$ In order to avoid the claim that 'might makes right', ${ }^{62}$ the international rule of law functions as the great equalizer among States, ${ }^{63}$ so that equality before international law can be achieved. ${ }^{64}$ Therefore, the norms of general international have to be agreeable to all ${ }^{65}$ and reflect a true universal consensus, ${ }^{66}$ while-with some reservations-upholding fundamental human values. ${ }^{67}$ As a result, the debates in the Sixth Committee point to an understanding where non-arbitrariness constitutes one of the core elements of the international rule of law. ${ }^{68}$

In the Colombian-Peruvian asylum case, the ICJ contrasted the rule of law with arbitrary political actions with the rule of law when it stated:

In principle, therefore, asylum cannot be opposed to the operation of justice. An exception to this rule can occur only if, in the guise of justice, arbitrary action is substituted for the rule of law. Such would be the case if the administration of justice were corrupted by measures clearly prompted by political aims. $^{69}$

ICJ further elaborated this point in the Elettronica Sicula S.p.A. (ELSI) (United States of America v. Italy) judgment:

${ }_{61}$ Qatar (A/C.6/72/SR.5, § 100); Syria n Arab Republic (A/C.6/72/SR.6, § 21), (A/C.6/69/SR.7, § 36).
${ }^{62}$ Mauritius (A/C.6/72/SR.6, § 91).
${ }^{63}$ Philippines (A/C.6/72/SR.5, § 94).
${ }^{64}$ Lao People's Democratic Republic (A/C.6/72/SR.5, § 90); Lebanon (A/C.6/72/SR.6, § 115); Bangla-
desh (A/C.6/69/SR.7, § 16).
${ }^{65}$ India (6th Committee, 72nd session, 5 October 2017, available at: http://statements.unmeetings.org/ media2/16152687/india.pdf); Dominican Republic speaking on behalf of CELAC (A/C.6/71/SR.4, § 84); Ecuador on behalf of CELAC (A/C.6/70/SR.5, § 41), Costa Rica, on behalf of CELAC (A/C.6/69/SR.5, $\S 5$ ); Singapore (6th Committee, 70th session, 14th October 2015, available at (http://statements.unmee tings.org/media2/7652815/singapore.pdf); Indonesia (A/C.6/70/SR.7, § 21); Pakistan (A/C.6/70/SR.7, § 95); China (A/C.6/69/SR.7, § 30).

${ }^{66}$ South Africa on behalf of the African Group (6th Committee, 71st session, 5th October 2016; available at: http://statements.unmeetings.org/media2/7661218/south-africa.pdf); 6th Committee, 70th session, 14th October 2015, available at: http://statements.unmeetings.org/media2/7652800/south-africa-onbehalf-of-the-african-group.pdf); China (A/C.6/70/SR.8, § 6); Republic of Korea (A/C.6/70/SR.8, § 1).

${ }^{67}$ India (6th Committee, 71st session, 6th October, available at: http://statements.unmeetings.org/ media2/7661336/india.pdf), (A/C.6/70/SR.7, § 94).

${ }^{68}$ Mauritius (6th Committee, 72nd session, 5 October 2017, available at: http://statements.unmeetings. org/media2/16152747/mauritius.pdf); Zimbabwe (A/C.6/72/SR.7, § 19); Kenya (A/C.6/72/SR.8, § 27); Japan (A/C.6/72/SR.8, § 29); Kenya (6th Committee, 71st session, 5th October 2016, available at: http:// statements.unmeetings.org/media2/7661337/kenya.pdf); Maldives (6th Committee, 71st session, 5th October 2016, available at: http://statements.unmeetings.org/media2/7661351/maldives.pdf); Senegal (6th Committee, 71st session, 6th October, available at: http://statements.unmeetings.org/media2/76613 90/senegal-final-.pdf); Canada on behalf of Canada, Australia and New Zealand [CANZ] (6th Committee, 70th session, 14th October 2015, available at http://statements.unmeetings.org/media2/7652805/ canada-on-behalf-of-canz.pdf); Singapore (6th Committee, $70^{\text {th }}$ session, $14^{\text {th }}$ October 2015 , available at (http://statements.unmeetings.org/media2/7652815/singapore.pdf); Bangladesh (6th Committee, 70th session, 14th October 2015, available at http://statements.unmeetings.org/media2/7652817/bangladesh. pdf); Poland (6th Committee, 70th Session, 14th October 2015, available at: http://statements.unmee tings.org/media2/7653004/poland-r1.pdf); Colombia (A/C.6/69/SR.5, § 68); Bangladesh (A/C.6/69/SR.7, $\S 16)$; Zimbabwe (A/C.6/69/SR.7, § 61).

${ }^{69}$ Colombian-Peruvian asylum case, Judgment, 20 November 1950, ICJ Reports (1950) 266, at 284. 
Arbitrariness is not so much something opposed to a rule of law, as something opposed to the rule of law. This idea was expressed by the Court in the Asylum case, when it spoke of "arbitrary action" being "substituted for the rule of law" (Asylum, Judgment, I.C.J. Reports 1950, p. 284). ${ }^{70}$

ICJ then defined arbitrariness as a wilful disregard of due process of law, an act which shocks, or at least surprises, a sense of juridical propriety. ${ }^{71}$ ICJ's understanding of non-arbitrariness as an element of the international rule of law appears to demand that any relevant exercise of power under international law requires a sufficiently legitimate basis in order to be justified. In this sense, it can be said that the restriction of arbitrariness as a core element of the international rule law is reflected in the jurisprudence of the ICJ.

\subsection{Predictability and Consistency}

Consistency bestows a certain conception of rationality to law and makes it more intelligible and thus predictable for the subjects. ${ }^{72}$ Therefore, consistency and predictability are interlinked and taken together for the purpose of the present analysis. In the words of Judge Sir Robert Jennings, '[1] aw develops by precedent, and it is that which gives it consistency and predictability'. ${ }^{73}$

In the Sixth Committee, CELAC ${ }^{74}$ and $\operatorname{ASEAN}^{75}$ have put much emphasis on the predictability of rules of international law as an element of the international rule of

${ }^{70}$ Elettronica Sicula S.p.A. (ELSI) (United States of America v. Italy), 20 July 1989, ICJ Reports (1989) 15 , at 76 , para 128.

71 Ibid.

${ }^{72}$ H.E. Judge Shunji Yanai, 'Statement to the United Nations General Assembly on the occasion of the commemoration of the thirtieth anniversary of the opening for signature of the 1982 United Nations Convention on the Law of the Sea',10 December 2012, at 5: 'The Tribunal must respond to the needs of the international community and do so by remaining consistent in its interpretation of the Convention so as to ensure the legal predictability counted on by the States Parties', available at: https://www.itlos. org/fileadmin/itlos/documents/statements_of_president/yanai/GA_Statement_30th_anniversary_101212. E_FINALE.pdf; M. Kumm, 'International Law in National Courts: The International Rule of Law and the Limits of the Internationalist Model', 44 Virginia Journal of International Law (2003) 19, at 25; N. MacCormick, Rhetoric and the Rule of Law-A Theory of Legal Reasoning (2005), at 201; MacCormick draws this connection between coherence and predictability and distinguishes between coherence and consistency. He interprets consistency as requiring non-contradiction, whereas coherence can be a matter of degree with some internal inconsistencies.

${ }^{73}$ Military and Paramilitary Activities in and against Nicaragua (Nicaragua v. United States of America), Jurisdiction and Admissibility, Judgment, 26 November 1984, ICJ Reports (1984) 392, Separate opinion of Judge Sir Robert Jennings, at 547.

${ }^{74}$ Dominican Republic speaking on behalf of CELAC (A/C.6/71/SR.4, § 80); Ecuador on behalf of CELAC (A/C.6/70/SR.5, § 41); Costa Rica, on behalf of CELAC (A/C.6/69/SR.5, § 5), reiterated by Bolivarian Republic of Venezuela (A/C.6/72/SR.7, § 91); Barbados (A/C.6/70/SR.8, § 30), Mexico (A/C.6/69/SR.7, § 41).

${ }^{75}$ Cambodia on behalf of ASEAN (A/C.6/72/SR.5, § 48), (A/C.6/71/SR.5, § 10), reiterated by Thailand (A/C.6/72/SR.7, § 9), (A/C.6/70/SR.7, § 49), Philippines (A/C.6/71/SR.7, § 73), (6th Committee, 70th session, 15th October 2015, available at: http://statements.unmeetings.org/media2/7653051/philippines. pdf), (A/C.6/69/SR.6, § 28), Singapore (6th Committee, 70th session, 14th October 2015, available at http://statements.unmeetings.org/media2/7652815/singapore.pdf); Indonesia (6th Committee, 70th session, 15th October 2015, available at: http://statements.unmeetings.org/media2/7652930/indonesia.pdf). 
law. Additionally, Austria, ${ }^{76}$ India, ${ }^{77}$ Slovenia, ${ }^{78}$ Kenya, ${ }^{79}$ Japan, ${ }^{80}$ Islamic Republic of Iran, ${ }^{81}$ Turkey, ${ }^{82}$ Belarus, ${ }^{83}$ United States of America, ${ }^{84}$ Republic of Korea, ${ }^{85}$ Ukraine, ${ }^{86}$ and Estonia ${ }^{87}$ have made statements to the same effect. Similarly, Israel, ${ }^{88}$ the African Group, ${ }^{89}$ Canada, Australia and New Zealand, ${ }^{90}$ and Bangladesh ${ }^{91}$ have associated legal certainty with the international rule of law. Likewise, the five Nordic Countries have stated that blurred legal situations would impede the international rule of law. ${ }^{92}$ Therefore, at least 117 States have expressed the view that predictability or certainty is an element of the international rule of law.

Other statements point to the importance of consistency in the application of legal rules for the international rule of law. Especially, the Movement of Non-Aligned States has stated on numerous occasions that selectivity in the application of international is incompatible with the international rule of law. ${ }^{93}$ This view has been shared

\footnotetext{
76 Austria (A/C.6/72/SR.5, § 62), (6th Committee, 71st session, 5th October 2016, available at: http:// statements.unmeetings.org/media2/7661270/austria.pdf), (6th Committee, 70th Session, 14th October 2015, available at http://statements.unmeetings.org/media2/7653014/austria.pdf), (A/C.6/69/SR.7, § 24).

77 (A/C.6/72/SR.6, § 14).

78 (A/C.6/72/SR.6, § 49).

79 (A/C.6/72/SR.8, § 28), (6th Committee, 71st session, 5th October 2016, available at: http://statements. unmeetings.org/media2/7661337/kenya.pdf).

80 (6th Committee, 72nd session, 6th October 2017, available at: http://statements.unmeetings.org/ media2/16152858/japan.pdf), (A/C.6/69/SR.5, § 85).

81 Islamic Republic of Iran (6th Committee, 72nd session, 5th October 2017, available at http://state ments.unmeetings.org/media2/16152832/iran-islamic-republic-of-.pdf).

82 (6th Committee, 71st session, 5th October 2016, available at: http://statements.unmeetings.org/ media2/7661261/turkey.pdf).

83 (A/C.6/71/SR.8, § 5), (A/C.6/70/SR.6, § 1 and $\S 3)$.

84 (A/C.6/70/SR.6, § 33).

85 (A/C.6/70/SR.8, § 1).

86 (A/C.6/69/SR.6, § 14).

87 (A/C.6/69/SR.6, § 79).
}

88 (A/C.6/72/SR.5, § 74), (6th Committee, 70th session, 15th October 2015, available at: http://state ments.unmeetings.org/media2/7652953/israel.pdf).

89 South Africa on behalf of the African Group (6th Committee, 71st session, 5th October 2016, available at: http://statements.unmeetings.org/media2/7661218/south-africa.pdf), reiterated by Mauritius (6th Committee, 72nd session, 5th October 2017, available at: http://statements.unmeetings.org/media2/ 16152747/mauritius.pdf), Senegal (A/C.6/71/SR.7, § 32),

90 Canada on behalf of Canada, Australia and New Zealand [CANZ] (6th Committee, 70th session, 14th October 2015, available at http://statements.unmeetings.org/media2/7652805/canada-on-behalf-of-canz. pdf).

91 (6th Committee, 70th session, 14th October 2015, available at http://statements.unmeetings.org/ media2/7652817/bangladesh.pdf), (A/C.6/69/SR.7, § 16).

92 (A/C.6/70/SR.5, § 61).

93 Islamic Republic of Iran on behalf of NAM (A/C.6/72/SR.5, § 23), (A/C.6/71/SR.4, § 89), (A/C.6/70/ SR.5, § 19), (A/C.6/69/SR.4, § 81), reiterated by ASEAN: Cambodia on behalf of ASEAN (A/C.6/72/ SR.5, § 48), (A/C.6/71/SR.5, § 10), Syrian Arab Republic (A/C.6/72/SR.6, § 20 f.), (A/C.6/70/SR.7, § 43 f.), (A/C.6/69/SR.7, § 36); Libya (A/C.6/72/SR.6, § 40); Mauritius (6th Committee, 72nd session, 5th October 2017, available at: http://statements.unmeetings.org/media2/16152747/mauritius.pdf); Viet Nam (6th Committee, 72nd session, 5th October 2017, available at: http://statements.unmeetings.org/ media2/16152801/viet-nam.pdf); Islamic Republic of Iran (A/C.6/70/SR.7, § 41), (A/C.6/69/SR.7, § 23), (A/C.6/69/SR.7, § 23); Lesotho (A/C.6/69/SR.5, § 60); Algeria (A/C.6/69/SR.6, § 92) and Saudi Arabia (A/C.6/69/SR.8, § 2). 
by China ${ }^{94}$ and Poland. ${ }^{95}$ Double standards ${ }^{96}$ and claims of exceptionalism ${ }^{97}$ in the application of international law have been described as inacceptable and as promoting politicization of law. ${ }^{98}$ Instead, a number of States have called for fairness ${ }^{99}$ and equality ${ }^{100}$ in international law. In this context, ASEAN ${ }^{101}$ and the African Group ${ }^{102}$ have described consistency as an element of the international rule of law.

The ICJ has discussed predictability and consistency together, as they may share similar identifiers and promote similar outcomes, without being the same, as conceptualised above. In the Continental Shelf (Libyan Arab Jamahiriya/Malta) case, the ICJ found that:

the justice of which equity is an emanation, is not abstract justice but justice according to the rule of law; which is to say that its application should display consistency and a degree of predictability; even though it looks with particularity to the peculiar circumstances of an instant case, it also looks beyond it to principles of more general application. ${ }^{103}$

The requirements of 'consistency and a degree of predictability' are not deduced from 'abstract justice' (equity contra legem), but from a rule of (positive) international law, which requires the application of equity ${ }^{104}$ (equity intra

${ }_{94}$ (A/C.6/72/SR.7, § 34), (A/C.6/70/SR.8, § 6).

95 (6th Committee, 70th Session, 14th October 2015, available at: http://statements.unmeetings.org/ media2/7653004/poland-r1.pdf).

${ }^{96}$ Cambodia on behalf of ASEAN (A/C.6/72/SR.5, § 48), Viet Nam (6th Committee, 72nd session, 5th October 2017, available at: http://statements.unmeetings.org/media2/16152801/viet-nam.pdf); Libya (A/C.6/72/SR.6, § 40); China (A/C.6/72/SR.7, § 34).

${ }^{97}$ Brazil (6th Committee, 72nd session, 5th October 2017, http://statements.unmeetings.org/media2/ 16152817/brazil.pdf), (A/C.6/71/SR.5, 74), Brazil (A/C.6/70/SR.8, § 24), (A/C.6/69/SR.6, § 50).

${ }^{98}$ Israel (A/C.6/72/SR.5, § 74), (A/C.6/70/SR.7, § 14); Syria (A/C.6/72/SR.6, § 21); Rwanda (A/C.6/72/ SR.6, § 104); Indonesia (6th Committee, 72nd session, 5th October 2017, available at: http://statements. unmeetings.org/media2/16152810/indonesia.pdf), Kenya (A/C.6/72/SR.8, § 28).

${ }^{99}$ Senegal (A/C.6/71/SR.7, § 32); Canada on behalf of Canada, Australia and New Zealand [CANZ] (6th Committee, 70th session, 14th October 2015, available at http://statements.unmeetings.org/media2/ 7652805/canada-on-behalf-of-canz.pdf); Pakistan (A/C.6/70/SR.7, § 95); Bangladesh (A/C.6/69/SR.7, § 16).

${ }^{100}$ Azerbaijan (A/C.6/72/SR.8, § 15); Estonia (A/C.6/70/SR.6, § 41); South Africa (A/C.6/69/SR.6, § 43); Austria (A/C.6/69/SR.7, § 24).

${ }^{101}$ Cambodia on behalf of ASEAN (A/C.6/72/SR.5, § 48), (A/C.6/71/SR.5, § 13).

102 South Africa on behalf of the African Group (6th Committee, 70th session, 14th October 2015, available at: http://statements.unmeetings.org/media2/7652800/south-africa-on-behalf-of-the-african-group. pdf), reiterated by Maldives (6th Committee, 71st session, 5th October 2016, available at: http://state ments.unmeetings.org/media2/7661351/maldives.pdf).

103 Continental Shelf (Libyan Arab Jamahiriya/Malta), Judgment, 3 June 1985, ICJ Reports (1985) 13, at 39 , para 45 .

${ }^{104}$ Continental Shelf (Libyan Arab Jamahiriya/Malta), Judgment, 3 June 1985, ICJ Reports (1985) 13, at 39, para 45: 'As the Court also said in its 1982 Judgment: 'Equity as a legal concept is a direct emanation of the idea of justice. The Court whose task is by definition to administer justice is bound to apply it.' (I.C.J. Reports 1982, p. 60, para. 71.) Yet the 'Application of equitable principles is to be distinguished from a decision ex aequo et bono' and as the Court put it in its 1969 Judgment: 'it is not a question of applying equity simply as a matter of abstract justice, but of applying a rule of law which itself requires the application of equitable principles, in accordance with the ideas which have always underlain the development of the legal régime of the continental shelf in this field' (I.C.J. Reports 1969, p. 47 , para. 85 ). 
legem). ${ }^{105}$ Unfortunately, the ICJ has not explained how it infers these requirements from that (positive) law.

In the Armed Activities on the Territory of the Congo case, Judge Elaraby issued a Separate Opinion, in which he explained that in the Continental Shelf (Libyan Arab Jamahiriya/Malta) case, the ICJ had intended to emphasise that there is a 'general desire for consistency and stability in the Court's case-law when the Court is dealing with legal issues which have been before it in previous cases' ${ }^{106}$

Even though the ICJ is not obliged to adapt its own interpretation to that of another judicial body, it has considered that it should nonetheless ascribe great weight to the pronouncements of other bodies that were established specifically for the purpose of supervising the application of norm in question. Thus, in the Ahmadou Sadio Diallo case the ICJ took due account of the interpretations of the other bodies in order to achieve the essential consistency of international law. ${ }^{107}$ Similarly, Vice-President Ranjeva, and Judges Guillaume, Higgins, Kooijmans, Al Khasawneh, and Buergenthal found in their joint declaration in the Legality of Use of Force (Serbia and Montenegro v. Germany) case that '[c]onsistency is the essence of judicial reasoning. This is especially true in different phases of the same case or with regard to closely related cases.' Any Court 'must ensure consistency with its own past case law in order to provide predictability.' 108

In order to ensure predictability, the requirement of consistency commands that norms of international law should be given the same meaning in every given case as long as it is appropriate--even if different tribunals are called upon to interpret it. ${ }^{109}$ This is a view shared also by other international courts. The International Criminal Tribunal for the former Yugoslavia has declared 'that in the interests of certainty and predictability', it 'should follow its previous decisions, but should be free to depart from them for cogent reasons in the interests of justice', such as when 'the previous decision has been decided on the basis of a wrong legal principles.' ${ }^{110}$ Similarly, the European Court of Human Rights (ECtHR) found a court that failed to develop a mechanism to ensue legal consistency to violate the principle of legal certainty and thereby, to act contrary to the rule of law. ${ }^{111}$ Accordingly, in the case law of international tribunals also

\footnotetext{
105 G. I. Hernández, The International Court of Justice and the Judicial Function (2014), at 67.

106 Armed Activities on the Territory of the Congo (Democratic Republic of the Congo v. Uganda), Judgment, 19 December 1995, ICJ Reports (2005) 168, Separate Opinion of Judge Elaraby, at 332, para 19.

107 Ahmadou Sadio Diallo (Republic of Guinea v. Democratic Republic of the Congo), Merits, Judgment, 30 November 2010, ICJ Reports (2010) 639, at 664, paras $66 \mathrm{f}$.

108 Legality of Use of Force (Serbia and Montenegro v. Germany), Preliminary Objections, Judgment, 15 December 2004, ICJ Reports (2004) 720, at 766.

109 Cf. also: President of the ICJ, R. Higgins, The ICJ and the Rule of Law (2007), at 6 f. available at https://archive.unu.edu/events/files/2007/20070411_Higgins_speech.pdf (last visited 27 February 2021).

110 ICTY, Zlatko Aleksovski, Appeal Judgement, 24.03.2000 (IT-95-14/1-A), para $107 \mathrm{f}$.

111 Beian v. Romania (no. 1), no. 30658/05, §§ 36-39, ECHR 2007-XI.
} 
beyond the ICJ consistency and predictability are acknowledged as elements of the international rule of law.

Predictability has also a connection to non-arbitrariness. The Inter-American Court of Human Rights has repeatedly stated that rules of law interfering with the rights of other subjects must be so predictable as to provide an adequate protection against arbitrariness ${ }^{112}$ - a view that can also be found in the practice of the ECtHR. ${ }^{113}$

It should be noted that outside of courts, international law sometimes evolves through deviations, a prime example of this being customary international law. Nonetheless, for such deviations to crystallise into legal rules, their practice must become consistent. In this sense, it is the rules of change and rules of interpretation, which convey a sense of predictability on the normative developments. ${ }^{114}$

\subsection{Other Elements}

At the UNGA, 76 States have identified accountability ${ }^{115}$ and 16 States the fight against impunity ${ }^{116}$ as an element of the international rule of law. Last but not least,

\footnotetext{
${ }_{112}$ IACtHR, Case of López Mendoza v. Venezuela, Judgment (Merits, Reparations and Costs), 1 September 2011, para 202; Case of López Lone et al. v. Honduras, Judgment (Preliminary objection, Merits, Reparations and Costs), 5 October 2015, para 264. All IACtHR decisions are available at http://www. corteidh.or.cr/index.php/en/jurisprudencia.

113 Malone v. the United Kingdom, no. 8691/79, § 68, [1984] ECHR 1984-X.

${ }^{114}$ For rules on interpretation of customary international law, see P. Merkouris, N. Arajärvi and J. Kammerhoffer (eds.), The Theory, Practice and Interpretation of Customary International Law (2021).

115 Cambodia on behalf of ASEAN (A/C.6/72/SR.5, § 48), reiterated by Thailand (A/C.6/72/SR.7, § 10), Indonesia (6th Committee, 72nd session, 5 October 2017, available at: http://statements.unmeetings.org/ media2/16152810/indonesia.pdf), Singapore (6th Committee, 70th session, 14th October 2015, available at (http://statements.unmeetings.org/media2/7652815/singapore.pdf); Denmark on behalf of the Nordic Countries (A/C.6/72/SR.5, § 60), (A/C.6/71/SR.5, § 27), Finland, speaking on behalf of the Nordic countries Denmark, Finland, Iceland, Norway and Sweden (A/C.6/69/SR.5, § 18); South Africa on behalf of the African Group (6th Committee, 71st session, 5th October 2016; available at: http://statements.unmee tings.org/media2/7661218/south-africa.pdf), reiterated by Mauritius (6th Committee, 72nd session, 5th October 2017, available at: http://statements.unmeetings.org/media2/16152747/mauritius.pdf), South Africa (A/C.6/69/SR.6, § 43); Lebanon (A/C.6/72/SR.6, § 115), (A/C.6/71/SR.5, § 64); Islamic Republic of Iran (6th Committee, 72nd session, 5th October 2017, available at: http://statements.unmeetings. org/media2/16152832/iran-islamic-republic-of-.pdf); Belarus (A/C.6/72/SR.8, § 8); Mexico (A/C.6/72/ SR.8, § 34); Bangladesh (6th Committee, 70th session, 14th October 2015, available at http://statements. unmeetings.org/media2/7652817/bangladesh.pdf), (A/C.6/69/SR.7, § 16); Estonia (A/C.6/70/SR.6, § 41), (A/C.6/69/SR.6, § 79);); India (A/C.6/69/SR.7, § 55).

${ }^{116}$ Switzerland (A/C.6/72/SR.5, § 78); Libya (A/C.6/72/SR.6, § 40); Trinidad and Tobago on behalf of the CARICOM (6th Committee, 71st session, 5th October 2015, available at: http://statements.unmee tings.org/media2/7661235/caricom.pdf), (6th Committee, 70th session, 14th October 2015, available at: http://statements.unmeetings.org/media2/7652796/trinidad-and-tobago-on-behalf-of-caricom.pdf), (A/C.6/69/SR.4, § 81); Denmark on behalf of the Nordic Countries (A/C.6/71/SR.5, § 27).
} 
57 States have described human rights as an element of the international rule of law. ${ }^{117}$

In addition, during the 2014-2017 sessions, 24 States suggested that transparency constituted an element of the international rule of law. ${ }^{118}$ While in many separate or dissenting opinions, judges have stressed the desirability of transparency in the reasoning of decisions of the ICJ ${ }^{119}$ and other tribunals, ${ }^{120}$ a general demand of transparency has not crystallised.

Similarly, the ICJ has not drawn any link between the international rule of law on the one hand, and accountability or the fight against impunity, on the other hand. Yet, the Trial Chamber of the International Criminal Tribunal for the former Yugoslavia proclaimed in the Erdemovic case that it was part of its mandate

to contribute to the settlement of the wider issues of accountability, reconciliation and establishing the truth behind the evils perpetrated in the former Yugoslavia. Discovering the truth is a cornerstone of the rule of law and a fundamental step on the way to reconciliation. ${ }^{121}$

It appears that the fight against impunity serves a function for the international rule of law in certain fields but it has not evolved to a level yet where it transcends international law in general so it could be considered to form a core of the international rule of law. However, as Judge Cançado Trinidade has noted in a separate opinion, the struggle against impunity may correspond to the demands of the

117 Bolivarian Republic of Venezuela (A/C.6/72/SR.7, § 92); Cambodia on behalf of ASEAN (A/C.6/71/ SR.5, § 10); Lebanon (A/C.6/71/SR.5, § 64); Kuwait (A/C.6/71/SR.7, § 66); Bangladesh (6th Committee, 70th session, 14th October 2015, available at http://statements.unmeetings.org/media2/76528 17/bangladesh.pdf); United States of America (A/C.6/70/SR.6, § 33); El Salvador (A/C.6/70/SR.8, $\S 6$ ); European Union, speaking also on behalf of Albania, Montenegro, Serbia and the former Yugoslav Republic of Macedonia; the stabilization and association process country Bosnia and Herzegovina; and, in addition, Georgia, the Republic of Moldova and Ukraine (A/C.6/69/SR.5, § 10); Qatar (A/C.6/69/ SR.5, § 52 f.); Libya (A/C.6/69/SR.5, § 58); Pakistan (A/C.6/69/SR.5, § 62); Morocco (A/C.6/69/SR.6, § 37); India (A/C.6/69/SR.7, § 55).

${ }^{118}$ Cambodia on behalf of ASEAN (A/C.6/72/SR.5, § 48), (A/C.6/71/SR.5, § 13); Israel (A/C.6/72/ SR.5, § 74), (6th Committee, 70th session, 15th October 2015, available at: http://statements.unmee tings.org/media2/7652953/israel.pdf); Cuba (A/C.6/72/SR.6, § 83); Mauritius (6th Committee, 72nd session, 5th October 2017, available at: http://statements.unmeetings.org/media2/16152747/mauritius. pdf); Islamic Republic of Iran (6th Committee, 72nd session, 5th October 2017, available at: http://state ments.unmeetings.org/media2/16152832/iran-islamic-republic-of-.pdf); Belarus (A/C.6/72/SR.8, § 8), (A/C.6/71/SR.8, § 5), (A/C.6/70/SR.6, § 3); Kenya (A/C.6/72/SR.8, § 27); Senegal (A/C.6/71/SR.7, § 32); Canada on behalf of Canada, Australia and New Zealand [CANZ] (6th Committee, 70th session, 14th October 2015, available at http://statements.unmeetings.org/media2/7652805/canada-on-behalf-ofcanz.pdf); Bangladesh (6th Committee, 70th session, 14th October 2015, available at http://statements. unmeetings.org/media2/7652817/bangladesh.pdf), (A/C.6/69/SR.7, § 16); United States of America (A/C.6/70/SR.6, § 33); Switzerland (A/C.6/69/SR.5, § 74); Morocco (A/C.6/69/SR.6, § 37).

119 Immunities and Criminal Proceedings (Equatorial Guinea v. France), Provisional Measures, Order of 7 December 2016, ICJ. Reports (2016) 1148, Declaration of Judge Gaja; Pulp Mills on the River Uruguay (Argentina v. Uruguay), Judgment of 20 April 2010, ICJ Reports (2010) 14, Joint dissenting opinion Judges Al-Khasawneh and Simma, at $114 \mathrm{f}$. para 14.

120 Arbitral Award of 31 July 1989, Judgment of 12 November 1991, ICJ. Reports (1991) 53, Joint Dissenting Opinion of Judges Aguilar Mawdsley and Ranjeva at 123 para 12.

${ }^{121}$ ICTY, Sentencing Judgment, Erdemnovic (IT-96-22-TI), Trial Chamber, 05 March 1998, § 21, available at: http://www.icty.org/x/cases/erdemovic/tjug/en/erd-tsj980305e.pdf. 
international rule of law, where impunity amounts to a violation of international legal obligations. ${ }^{122}$

Although the ICJ has not explicitly taken up the proposition that human rights formed part of the international rule of law, it has nevertheless acknowledged a connection between non-arbitrariness and human rights. In the Ahmadou Sadio Diallo (Republic of Guinea v. Democratic Republic of the Congo), the Court held that 'protection against arbitrary treatment lies at the heart of the rights guaranteed by the international norms protecting human rights. ${ }^{123}$ This view has also been accepted in the jurisprudence of the ECtHR. ${ }^{124}$ It thus seems that despite not forming part of the international rule of law in their own right, international human rights standards are one of the ways in which the non-arbitrariness demanded by the international rule of law can manifest itself.

While the review of States' verbal practice in the Sixth Committee has demonstrated that also 'thick' concepts, such as human rights, accountability and the fight against impunity are embraced by a non-neglectable number of States, the ICJ has been much more cautious. The focus on non-arbitrariness, predictability and consistency as elements of the international rule of law in the jurisprudence of the ICJ can be explained, however, by a desire to stick to a rather non-substantive definition of the international rule of law.

\section{Concluding Remarks}

What kind of international rule of law is generally supported by States? While several States have proposed a variety of 'thick' definitions, many have argued that there cannot be 'no one size fits all' model for the international rule of law. The core requirements of international rule of law should be generally accepted; they should not face broad contestation or have their fundamental nature often questioned. They provide stability and continuity, even when values and structures around them change and develop. Through a study of the rule of law debates in the General Assembly during a five-year period, I have identified non-arbitrariness, consistency and predictability as the core requirements of the international rule of law. This conclusion finds support in the jurisprudence of the ICJ. Similarly, if through a different methodological approach-by relying on the doctrine of pacta sunt servanda as enshrined in customary international law and as part of jus cogens-Robert

\footnotetext{
122 Questions relating to the Obligation to Prosecute or Extradite (Belgium v. Senegal), Judgment of 20 July 2012, ICJ Reports (2012) 422, Separate Opinion of Cançado Trinidade at 515 f. para. 71-76.

${ }^{123}$ Ahmadou Sadio Diallo (Republic of Guinea v. Democratic Republic of the Congo), Merits, Judgment, 30 November 2010, ICJ Reports (2010) 639, at 663, para 66.

124 Roche v. the United Kingdom [GC], no. 32555/96, § 116, ECHR 2005-X: '... the principles of the rule of law and the avoidance of arbitrary power which underlay much of the Convention'; Taxquet $v$.

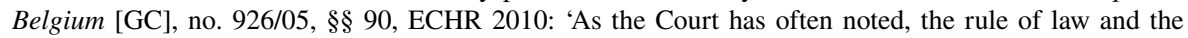
avoidance of arbitrary power are principles underlying the Convention'.
} 
McCorquodale has asserted that "two of the objectives of the international rule of law are legal order and stability, and equality of application'. ${ }^{25}$

The review of State practice reveals that thin and procedural definition of the international rule of law-while generally accepted-is complemented by calls for more substantive elements such as human rights, fight against impunity and accountability. These may fall under the broader umbrella of the rule of law but to argue that they are core requirements would dilute the normative specificity and clarity of the meaning of the international rule of law.

This contribution-with the objective of identifying core requirements of the international rule of law through engagement in positivist methodology-does not incorporate lengthy discussion of aspirational themes, such as democracy or transparency, which are not firmly established in the basic structure of the international legal system or even the requisites of national legal orders. ${ }^{126}$ This problematique is analogous to the expansion of human rights paradigm and its challenges: its core legal elements-which may, arguably, be seen as universally accepted-have become entangled with contrasting political aims, and 'human rights' has become interchangeable with 'human rights law'. ${ }^{127}$ For this reason, the ambition of this contribution has been to focus on the strict legal identification and limited usage of the notion of the international rule of law.

Focus on the core requirements of the international rule of law restricts the concept from becoming a catch-all category, it elevates the rule of law and separates its core essence from political, moral and other extra-legal considerations. The identification of these core requirements also suggests that the idea of international rule of law has concretised into a meaningful concept, which can be found through law, not only politics. Since Simon Chesterman in 2008 noted that '[a]t the international level anything resembling even this limited idea of the rule of law remains an aspiration', ${ }^{128}$ the international rule of law has become not just a catch word to justify any agenda and common parlance to be uttered by politicians at every $\operatorname{turn}^{129}$ but

\footnotetext{
125 R. McCorquodale 'Defining the International Rule of Law: Defying Gravity', 65 (2) International and Comparative Law Quarterly (2016) 277, at 296.

126 J. Crawford, Chance, Order, Change (2014), at 395 and 400; cf. J. Raitio, 'Does the concept of rule of law.

have any material content? A Nordic point of view', 24 (6) Maastricht Journal of European and Comparative Law (2017) 774.

127 ' $\ldots$ as the international human rights domain has grown and continued to spread, the range of critical reactions in turn has spread and intensified.', G. de Búrca, 'Human Rights Experimentalism', 111 (2) American Journal of International Law (AJIL) (2017) 277, at 278; cf. J. Tasioulas, 'Minimum Core Obligations: Human Rights in the Here and Now', The World Bank Research Paper, October 2017, available at https://openknowledge.worldbank.org/handle/10986/29144 (last accessed 27 February 2021) and J. Tasioulas, 'Saving Human Rights from Human Rights Law', 52 Vanderbilt Journal of Transnational Law (2019) 1167.

128 S. Chesterman, supra note 4, at 361.

129 As Tara Smith notes: 'On questions of international assistance, investment, and diplomacy, the Rule of Law has become something of a gold standard of legitimacy', in T. Smith, 'Neutrality Isn't Neutral: On the Value-Neutrality of the Rule of Law', 4 (1) Washington University Jurisprudence Review (2011) 49 , at 53 .
} 
a fundamental conceptual tool, alongside human rights, development and peace and security, which is here to stay-even if its substance is plagued with 'persistent vagueness' ${ }^{130}$ The rule of law, as noted by the President of Cyprus at the 2012 High-level Meeting on the Rule of Law at the National and International Levels and quoted at the start of this contribution, can be the greatest unifying factor and the nearest we are likely to come to a universal principle, but only if its conceptual clarity is fostered by focusing on its core requirements and stripping off the value-laden extra trimmings.

Acknowledgements A very early version of this paper was presented at the 2017 ESIL Research Forum in Granada, where I received extremely useful comments from Professor Pazartzis. I remain most grateful to Julian Kulaga for his work on compiling the data and contributing to an early draft as well as for the members of the Kolleg-Forschungsgruppe 'The International Rule of Law - Rise or Decline?' for giving us the opportunity to present and discuss the draft. Last but not the least, I thank the editors of HJRL and the anonymous reviewers for their careful reading and constructive comments and suggestions.

Funding Open Access funding enabled and organized by Projekt DEAL.

Open Access This article is licensed under a Creative Commons Attribution 4.0 International License, which permits use, sharing, adaptation, distribution and reproduction in any medium or format, as long as you give appropriate credit to the original author(s) and the source, provide a link to the Creative Commons licence, and indicate if changes were made. The images or other third party material in this article are included in the article's Creative Commons licence, unless indicated otherwise in a credit line to the material. If material is not included in the article's Creative Commons licence and your intended use is not permitted by statutory regulation or exceeds the permitted use, you will need to obtain permission directly from the copyright holder. To view a copy of this licence, visit http://creativecommons.org/licen ses/by/4.0/.

Publisher's Note Springer Nature remains neutral with regard to jurisdictional claims in published maps and institutional affiliations.

${ }^{130}$ B. Fassbender, 'What's in a Name? The International Rule of Law and the United Nations Charter', 17 Chinese Journal of International Law (2018) 761. 